\title{
Featuring Knowledge as the Means to the Essence of Creation: An Islamic Exposition
}

\author{
Usman Jimoh Muhammad \\ Federal College of Education Zaria, Nigeria \\ mujnar@yahoo.com
}

Received: August 28, 2021

KAT A KUNCI

Knowledge

The Essence of Creation Islam
Revised: September 25, 2021

Accepted: October 03, 2021
AB STRAK

The paper dwells on the crucial role of knowledge in the life of man. Knowledge is presented as a means to realization of the purpose for which man came into the world which is "to worship God. Knowledge as classified in the paper has two branches of which are Fard ayn (knowledge which is incumbent on everyone) and Fard Kifayah (knowledge which is needed to be acquired by some and not everyone). The paper buttresses the necessity of the two categories of knowledge towards attaining the desire to worship God accordingly. Viewing the fact that after the creation of man, knowledge was the first endowment given to man and the first promise made to him on his way to the earth one is bound to believe in the necessity of knowledge towards realisation of the purpose of creation. Relying on the fact that the first revelation emphasises on the search for knowledge; the stipulation for acquisition of knowledge before exhibition of actions coupled with the relevance of professional knowledge to ease of life and worship, it is justifiable to conclude that knowledge is a means towards realization of the essence of creation. This assertion is greatly reinforced with the aid of relevant Qur'anic text and prophetic traditions. The paper recommends that parents should ensure that their children receive sound knowledge of Islam as well as any other aspects of the knowledge that is Fard kifayah.

This is an open-access article under the CC-BY-SA license.

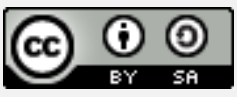

\section{Introduction}

The word ilm ( علم ( which means knowledge is derived from three alphabets namely, ain ( $(\varepsilon)$, lam (J) and mim ( ) ( ) that means to know. The term knowledge entails the awareness of a thing with regards to its reality (Asfahani, Muhammad, \& Qasim, 1992). Knowledge is articulated information that transforms someone or something thereby resulting into an action (Drucker 1989 \& Brooking 1999). Knowledge entails a theoretical (explicit) or practical (implicit) understanding of something which could be formal; informal; systematic or particular (Augus \& Christine, 2010). 
With regards to its categorisation, (Al-Ghazali, 2001) posits that knowledge is categorized into two main categories. These are (fardu 'ayn) meaning the individually needed knowledge and (fardu kifayah) meaning the aspect of knowledge needed by at least some members of the community in order to attend to societal need. The first category of knowledge has to do with the knowledge needed to worship God. This knowledge entails knowledge about tawhīd (i.e., unity of God, knowledge about fiqh (Islamic jurisprudence), and knowledge about akhlāq (virtue and good character). From the Islamic perspective, knowledge covers all aspects of life. With the aid of knowledge, man is able to achieve the most desirable solution to problems. Knowledge enables one to take appropriate decision when posed before a challenge. Science in Islam (Kosim, 2008) has distinctive characteristics that are fundamentally different from the sciences developed in the West, both on a solid foundation through the Qur'an and Sunnah, sources, means, and methodologies. So the scope of knowledge is very broad, not only concerning worldly issues, but also related to ukhrāwi problems.

\section{Method}

The paper exploits a literature approach as it consults relevant document deposited in libraries such as textbooks, academic journals and articles related to the work. To achieve a logical presentation, the paper identifies some major headlines which are sequentially explained. The method of gathering data from library sources, reading and taking notes, and processing research materials are all part of library research, which is also known as literature study (Sugiyono, 2019). Moreover, Sari \& Asmendri (2018) defined that library research as a type of study that entails reading books, magazines, and other sources to gather information from a variety of sources, whether in libraries or elsewhere. These issues were buttressed with the aid of relevant Qur'anic verses, authentic prophetic traditions and historical evidences related to the topic. This method accords the paper a colorful output and appreciable discussion and conclusion.

\section{Results and Discussion}

\section{The essence of creation}

The generic understanding and belief regarding the essence of creation is that man was purposely created for nothing but to worship God the Creator. This is an affirmation enshrined in the Qur'an. In Qur'an (51:56). Allah says: I have only created Jinns and men, that they may serve Me. Although the above is the aim behind the creation of man but one main fact is that the attainment of the above hinges on acquisition of knowledge, that is the first category of knowledge which is incumbent on everyone. 
Nonetheless, unlike the personally required type of knowledge (fardu 'ayn), the second category of knowledge (fardu kifayah) is not incumbent on everyone but it is necessary for some members of the society to have it so that they could cater for the needs of the generality. The society needs to have some people as teachers, doctors, policemen, soldiers and the rest but not all should fall in one category or the other. It is therefore a contributive factor to sustenance of life so that man could be opportune to realize the essence of creation (to worship God).

Evidences abound in the Glorious Qur'an and authentic prophetic traditions regarding the significance of knowledge to the attainment of the essence of creation. Similarly, there are sources emphasizing that all mundane activities inevitably require knowledge for sustenance of life which in turn accords man the opportunity to worship his lord accordingly. The antecedent surrounding the creation of Adam and the aftermath lessons as discussed in the next paragraphs clarify further.

\section{Endowment of knowledge as the first honour given to man}

Prior to the creation of Adam, the angels saw themselves as the closest and most dignified beings which Allah would ever create simply because they were in total and constant obedience to Allah. When Allah informed them about His decision to create His vicegerent on earth, they were astonished and as well fearful as they felt that this type of creature may create havoc and exhibit turbulent acts on earth. Based on their own little understanding, they felt that if the essence of creating such a creature is for Him to be worshipped, there may be no need for that. Their rationale was that after all, they (the angels) are constantly praising and glorifying Him. In response to their worries, Allah made it known that He is well acquainted with the knowledge of things which they do not know. In Qur'an (2:30) Allah says:

Behold, thy Lord said to the angels: "I will create a vicegerent on earth. "They said: "Wilt

Thou place therein one who will make mischief therein and shed blood?- whilst we do celebrate Thy praises and glorify Thy holy [name]?" He said: "I know what ye know not."

After the creation of Adam, the first gift which God Almighty endowed him with was the gift of knowledge of everything. Following this, was God's instruction to the Angels to mention the names of those things, a test which they could not pass Qur'an (2:32) says:

And He taught Adam the names of all things; then He placed them before the angels, and said: "Tell me the names of these if ye are right." They said: "Glory to Thee, of knowledge We have none, save what Thou Hast taught us: In truth it is Thou Who art perfect in knowledge and wisdom.

To buttress the pre-eminence of Adam over the Angels and express the ignorance of the Angels in the sight of Allah, Qur'an (2:33) says: 
He said: "O Adam! Tell them their names." When he had told them, Allah said: "Did I not tell you that I know the secrets of heaven and earth, and I know what ye reveal and what ye conceal?

(Qutb,2003) notes that man, having been chosen as God's vicegerent on earth, was granted the great secret of knowledge and the ability to recognize symbols and names of things. This enables human life to function well and accords man the ability to exhibit all forms of function on earth. The Angels were devoid of this ability to use names and symbols as it was not necessary for the function which they were meant for. After granting man this great favour and honour, He instructed the angels to identify the names of things placed before them but they could not. They however admitted their inability to use names and expressed the limitation of their knowledge. In the next paragraph, effort is made to position knowledge as an essential factor needed to realize the essence of creation as inspired from the promise made by Allah to man.

\section{Knowledge the foremost promise of Allah to man}

At the point of coming down to the earth which was after the incident of eating of the forbidden fruit by Adam, Allah promised to enlighten man and guide him by sending messengers and atimes. The following Qur'anic verse speaks further on this fact. We said: Get ye down all from here; and if, as is sure, there comes to you Guidance from me, whosoever follows My guidance, on them shall be no fear, nor shall they grieve. (Qur'an 2: 38)

He said: "Get ye down, both of you,- all together, from the Garden, with enmity one to another: but if, as is sure, there comes to you Guidance from Me, whosoever follows My Guidance, will not lose his way, nor fall into misery. But whosoever turns away from My Message, verily for him is a life narrowed down, and We shall raise him up blind on the Day of Judgment. Qur'an (20:123).

The above fulfilled promise of Allah to man actually means knowledge about Allah and his creation. With the aid of this knowledge, man is able to understand the world, realize the essence of creation and enabled to embrace the worship of the creator as expected. The following verse of the Glorious Qur'an further explains that God fulfills his promise on man by enabling him with means through which he could acquire knowledge.

It is He Who brought you forth from the wombs of your mothers when ye knew nothing; and He gave you hearing and sight and intelligence and affections: that ye may give thanks [to Allah]. Qur'an: (16:78)

The above verse testifies that every man came in to this world through the womb of his mother knowing nothing. However, God, in His infinite mercy, grants man the organs through which he could gradually understand things and acquire knowledge of various kinds. This knowledge would eventually lead man to realization of God, appreciation of His enormous 
blessing and the need to worship none but Him.

\section{The search for knowledge as the first revelation in Islam}

For decades, the humanity was in darkness due to absence of a messenger to guide them to the right path and as a result of non-existence of a divine revelation. This brought the Arabs for example to a stage of life that is being referred to as Jahiliyyah period ("the period of ignorance"). In a bid to guide man towards the essence of creation, a messenger was raised and a divine revelation was revealed to him bit by bit. To understand the significance of knowledge towards realization of the essence of creation, the first revelation centres on seeking for knowledge. The revelation came to Prophet Muhammad (S.A.W.) at Gharul-Hira (Cave of Hira) where he had his regular meditation. This incident as reflected in Bukhari (1997: vol., 1 no. 3, p47) affirms that:

The angel came to him and asked him to read. The Prophet replied, "I do not know how to read. The Prophet added, "Then the angel caught me (forcefully) and pressed me so hard that I could not bear it any more. He then released me and again asked me to read and I replied: 'I do not know how to read. 'Thereupon he caught me again and pressed me a second time till I could not bear it any more. He then released me and again asked me to read, but again I replied: 'I do not know how to read (or what shall I read?)'.Thereupon he caught me for the third time and pressed me, and then released me and said: 'Read in the Name of your Lord, Who has created (all that exists). Has created man from a clot (a piece of thick coagulated blood). Read! And your Lord is the Most Generous.'" (V.96:1-3)

The above revelation clearly shows that knowledge is the first thing needed by a man before he could achieve the essence of creation. All the five verses of the first revelation Qur'an (96:1-5) emphasises on knowledge.

\section{The necessity of Knowledge before action}

A very quick look at the injunction in the following Qur'anic verse attests to the fact that acquisition of knowledge is the first desirable thing before exhibition of an action. The verse says: And pursue not that of which thou hast no knowledge; for every act of hearing, or of seeing or of [feeling in] the heart will be enquired into [on the Day of Reckoning]. Qur'an (17:36). The above verse according to (Qutb, 2003) illustrates the need to have knowledge before uttering a statement or exhibiting an action. This knowledge according to the verse must also be based on certainty. The verse proceeds to stress the spirit of accountability as it affirms that (hearing, seeing and feelings) shall give an account of their actions before the creator. These organs are mentioned as they are the organs granted to man for acquisition of knowledge. In the following prophetic tradition, (Ibn Majah, 2007: vol. 1, no 572, 390-391), the significance of knowledge 
before issuance of a verdict or exhibition of an action is clearly illustrated.

It was narrated that 'Atti' bin Abu Rabih said: "I heard Ibn.Abbas saying that a man was injured in the head at the time of the Messenger of Allah then he had a wet dream. He was told to have a bath, so he took the bath, became rigid and stiff, and died. News of that reached the Messenger of Allah and he said: 'They have killed him, may Allah kill them! Is not the cure for a lack of knowledge to ask questions?' 'Ati' said: "We heard that the Messenger of Allah said: 'If only he had washed his body and left his head alone where the wound was.

A hadith of (Tirmidhi, 2007: vol. 4, no. 2518, p510) also validates the significance of knowledge before exhibition of an action. The hadith says: Al-Hasan bin 'Ali said: I remember that the Messenger of Allah said: Leave what makes you in doubt for what does not make you in doubt. The truth brings tranquility while falsehood sows doubt. All the above illustrations show the vitality of knowledge before one could do any act or make utterances both of which could be in form of worship or in interpersonal relation such as worship or towards realisation of the essence of creation.

During his life time, prophet Muhammad (SAW) sent emissaries to foreign rulers, in a bid to further the course of Islam. In all his messages to them, the first thing he did was to enlighten them about God Almighty. After he had enlightened them, he requested them to accept the message of Islam and worship God Almighty. The leaders invited include the Negus of Abyssinia, Muqawqas of Egypt, Chosroes the Emperor of Persia, Caesar, the King of Rome, Mundhir bn. Sawa, Governor of Bahrain, Haudha bn. 'Ali, Governor of Yamama, Harith AlGhassani, the King of Damascus.

Maintains that a cursory look at the Makkan surahs reveals that the chapters were mostly based on the concept of oneness of Allah which is all about enlightenment (Osman, 1991). This enlightenment resulted into total conviction and acceptance of Islam by the early Muslims and consequently their desire to worship God Almighty alone. In the following prophetic traditions, prophet gives credence to knowledge as a factor to be considered first when it comes to leadership in prayer.

The person who recites the most of Allah's Book should lead the people in prayer, and the one who has been reciting the longest. If they are equivalent in recitation, then the one who performed the Hijrah earlier should lead. If they are equivalent in the Hijrah, then the one who is older should lead. And no person should be led (by another) in his house or in his place of authority, nor should any one sit on his Takrimah except with his permission." Dawud (2008: vol 1. No 582, pp 357-358). 
When the earliest emigrants came to Al-Uba, a place in, before the arrival of the Prophet, Säi, the slave of Abu Hudhaifa, who knew the Qur'an more than the others, used to lead them in Salat (prayer). (Bukhari, 1997: vol. 1 no 692, pp395-396)

Amr bin Salama narrated how he embraced Islam. In the hadith, it proceeded to explain how they were instructed to present the most learned person to lead them in the daily prayers.The Prophet afterwards said to them:

Offer such and such Salat (prayer) at such and such time and when the time for the Salat (prayer) becomes due, then one of you should pronounce the Adhãn (for the Salat), and let the one amongst you who knows the Qur'an most should lead the Salãt (prayer) ." So they looked for such a person and found none who knew more of the Qur'an than I because of the Quranic Verses which I used to learn from the caravans. They therefore made me their Imam (Bukhari, 1997:vol. 5 no 4302, pp359-360)

\section{Allah's unveiling of Himself to man through knowledgeable.}

Among the Islamic beliefs is that no eye can see Allah in this world. However, worshipping Him is an obligation expected of each and every human being. To ensure that man knows and therefore worships Allah alone, the Almighty Allah promised to enlighten man about Himself. The following are textual evidences buttressing the above assertion. Qur'an (41:53) says: Soon will We show them our Signs in the [furthest] regions [of the earth], and in their own souls, until it becomes manifest to them that this is the Truth. Is it not enough that thy Lord doth witness all things? Qur'an (27:93) says Praise be to Allah, Who will soon show you His Signs, so that ye shall know them"; and thy Lord is not unmindful of all that ye do. Verily! in the creation of the heavens and the earth, and in the alternation of night and day, there are indeed signs for men of understanding. Those who remember Allah (always, and in prayers) standing, sitting, and lying down on their sides, and think deeply about the creation of the heavens and the earth, (saying): "Our Lord! You have not created (all) this without purpose, glory to you! (Exalted be you above all that they associate with you as partners). Give us salvation from the torment of the Fire. (Q.3:190-191).

This enlightenment facilitated the realization of the creator and the need to worship Him.

\section{Knowledge and its noble status in Islam}

Knowledge occupies great position in Islam as enunciated in various verses of the Qur'an and prophetic traditions. Because of its noble status and its desirability, searching for knowledge is made incumbent on every Muslim. The hadith says:

Seeking knowledge is a duty upon every Muslim, and he who imparts knowledge to those who do not deserve it, is like one who puts a necklace of jewels, pearls and gold around the neck of wines. (Ibn. Majah, 2007:vol. 1, no. 224, p222). 
The hadith buttresses the crucial nature of knowledge to man's life. Although the basic knowledge is considered as an obligation on every Muslim, other fields of knowledge are equally needed for sustenance of man's life. Knowledge is further portrayed in (Tirmidhi, 2007: vol. 6, no 3488, p205) as something which every Muslim should aspire to have:

Hishãm bin Hassan narrates from Al-Hasan concerning the saying of Allah: O our Lord, give us good in this world, and good in the Hereafter He said: "Knowledge and worship in this world and Paradise in the Hereafter.

(Tirmidhi, 2007: vol. 3 no. 1376, pp167-168) also narrates that: the Messenger of Allah said:

When a person dies, his deeds are cut off except for three: Continuing charity, knowledge that others benefited from, and a righteous son who supplicates for him.

The above hadith stresses the importance attached to knowledge in Islam as a scholar is rewarded even after his death for the knowledge, he impacted on a fellow being who utilizes it. The honour and regard given to a seeker of knowledge is buttressed in the following verse of the Glorious Qur'an. There is no god but He: That is the witness of Allah, His angels, and those endued with knowledge, standing firm on justice. There is no god but He, the Exalted in Power, the Wise. Qur'an (3:18). Those truly fear Allah, among His Servants, who have knowledge: for Allah is Exalted in Might, Oft-Forgiving. (Qur'an 35:28).

The significance of knowledge is further illustrated by the prophet regarding the prisoners of the Battle of Badr. (Ibn Ishaq, (2004) explains that after the Badr, knowledge was considered as a means of prisoners' self-emancipation from the yoke of slavery, for those who possess it. Therefore, some war prisoners who could not afford to pay any ransom but were literate were in lieu of the money, requested to gain their freedom by teaching ten Muslim children the art of reading and writing. Among the fortunate Muslims taught by these literate war prisoners was Zaid b. Thibit. Zaid later became one of the scribes of the prophet (SAW). There are quite a number of prophetic traditions on the noble status of a scholar. The following are some of them.

Abu Umamah Al-Bahili narrated: "Two men were mentioned before the Messenger of Allah. One of them a worshipper, and the other a scholar. So the Messenger of Allah said: 'The superiority of the scholar over the worshipper is like my superiority over the least of you.' Then the Messenger of Allah said: 'Indeed Allah, His Angels, the inhabitants of the heavens and the earths even the ant in his hole, even the fish say Salat upon the one who teaches the people to do good." Tirmidhi (2007: vol. 5, no 2685, p 80,) 
Abu Hurairah said There is no man - who follows a path in pursuit of knowledge but Allah will make easy for him a path to Paradise, - and if a person's deeds slow him down, his lineage will not help him to speed up (Abu Dawud, 2008: vol 4. no 3643, p208)

It was narrated that Zirr bin Hubaish said: "I went to Safwan bin 'Assal Al-Muradi and he said: 'What brought you here?' I said:, am seeking knowledge.' He said: 'I heard the Messenger of Allah say: "There is no one who goes out of his house in order to seek knowledge, but the angels lower their wings in approval of his action (Ibn Majah, 2007: vol. 1 no. 226.p 223)

(Ibn. Majah, 2007: vol. 1, no. 220, p219) says: It was narrated that Abu Hurairah said: "The Messenger of Allah said: 'When Allah wills good for a person, He causes him to understand the religion. In (Muslim, 2007: vol. 7. no. 6853, p73), prophet says: Whoever follows a path seeking knowledge, Allah will make a path to Paradise easy for him.

The following verse of the Qur'an explains the benefit of utilizing the message contained in the divine book.

He said: "Get ye down, both of you,- all together, from the Garden, with enmity one to another: but if, as is sure, there comes to you Guidance from Me, whosoever follows My Guidance, will not lose his way, nor fall into misery. Qur'an (20:123)

In his exposition of the above verse, (Ibn Kathir, 2003: vol 6, p 405) says that: Ibn `Abbas said, "He will not be misguided in this life and he will not be distressed in the Hereafter. The significance of knowledge cannot be overemphasised. In (Bukhari, vol. 1. no. 100, p 115), prophet says:

Allah does not take away the knowledge by taking it away from (the hearts of) the people, but takes it a away by the death of the religious learned men till when none of the religious learned men remains, people will take as their leaders ignorant persons who when consulted will give their verdict without knowledge. So they will go astray and will lead the people astray.

However, it is important to note that embracing the divine message of guidance which is full of wisdom, leads one to the straight path in this world. Similar benefit is enjoined when man utilizes all other forms of knowledge which Allah (SWT) endowed man with. As man utilizes the knowledge of medicine, technology, and all other fields of knowledge that are not against the religion of Islam but rather good for it, his life is made easy. This would in turn accord man an opportunity to worship God better.

\section{Professionalism and ease of worship}

Ibadah merupakan sebuah nama yang mencakup segala aktifitas yang disenangi Allah dan diridhai-Nya, baik yang berupa perkataan maupun perbuatan, baik yang bersifat lahiriyah 
maupun bathiniyah (Anam, 2017). Worship is a name that includes all activities that are pleasing to Allah and pleasing to Him, both in the form of words and deeds, both outwardly and inwardly.

Although man was created to worship God, the ease of worship is attainable only by means of knowledge. The said knowledge is not restricted to the Islamic knowledge alone but encompasses all knowledge useful to man's life. This brings to light the relevance of professional knowledge to ease of worship. Man as the vicegerent of Allah on earth is granted all forms of blessings to make life easy for him and enable him worship his lord accordingly. The Qur'an says: And He giveth you of all that ye ask for. But if ye count the favours of Allah, never will ye be able to number them. Verily, man is given up to injustice and ingratitude. Qur'an (14:34).

In the 5th year after hijrah, Banu Nadhir led by their leader, Nadir bn. Akhtab, sought for the cooperation of the pagan Quraysh and other tribes in Makkah, such as Banu-Ghatafan and Banu-Ghaylan with the intent of bringing an end to the life of the Muslims in Madinah. They approached Madinah with soldiers of about 10,000 people while 3000 Muslims were gathered by the prophet (SAW) to challenge them. Fortunately, Salman Al-Faris, in view his knowledge of warfare of the Persians' suggested the digging of a ditch round the city of Madinah. This paved way for the triumph of the Muslims over them and promoted sustenance of worship of Allah on earth. The above illustrates the necessity of professional knowledge for attainment of the essence of creation.

A hadith narrated by Abu Dawud further illustrates the importance of professional knowledge in Islam. In a bid to promote conveyance of the message of Islam to the Jews, the prophet at a point needed a Muslim to learn their writings. The following prophetic tradition in (Dawud, vol. 4 no. 3645, p 209) substantiates the above.

Zaid bin Thabit said: "The Messenger of Allah ordered me to learn the writing of the Jews, and said: 'By Allah, I do not trust the Jews to write for me.' So I learned it, and barely half a month had passed before I mastered it. I used to write for him when he wanted something written, and I used to read for him when something was written to him.

Similar tradition is contained in (Tirmidhi, vol. 5, no. 2715 p103). In the days of revelation, Qur'an was written on parchment, bone fragments and leather materials. With the introduction of paper-making into Samarqand by the prisoners in 751, it was given utmost attention such that it became part of their export product that was widely recognized and utilized (Bloom, 2001) This advancement in knowledge brought about ease and fast dissemination of knowledge and its preservation. It also prompted the copious volumes of Islamic books written to enlighten the Muslims in particular and the world in general. 
As time goes on, the Muslims progressed scientifically and technologically. This advancement in knowledge resulted into a number of ease in observance of worship and propagation of the religion. For example, with the advent of microphone, the voice of the caller for prayer is able to reach far and near while vast majority of Muslims are able to follow the Imam in congregational prayer. Knowledge also aided the ease at which Muslims troop into Makkah for the annual pilgrimage. This is as a result of the movement from the old tradition of horses and camels as means of transportation to the current trend of aero plane that conveyed thousands of worshippers easily and swiftly from their respective countries to Makkah.

\section{Knowledge and moral rearmament}

Beside the observance of the Islamic rituals and worship, Islam basically postulates the rearmament of moral values and inculcation of ethical teachings in man. The function of moral education or moral education is to protect someone from bad deeds or bad deeds that are not in accordance with existing norms in education, society, nation and state (Rubini, 2019). These teachings are of great important in man's relationship with his creator and in his relationship with all animate and inanimate creatures. The significance of knowledge is discernible in the life of the early Muslims. The transformation of their life from Jahiliyyah which was commonly associated with corruption, barbarism, egoistical nature to a responsible and sympathetic lifestyle was attained true knowledge.

In Adab -Al-Mufrad (Bukhari, 2007), prophet categorically declares that I was sent to perfect good character. In Qur'an (68:4) and Qur'an (33:21). Respectively Allah affirms that prophet was able to attain the highest echelon moral status and as such stand as the best example for man. Ye have indeed in the Messenger of Allah a beautiful pattern [of conduct]for any one whose hope is in Allah and the Final Day, and who engages much in the Praise of Allah. And thou [standest] on an exalted standard of character. The state of human heart determines the nature of its utterances and actions.

In (Bukhari, 1997:vol. 1 no. 52, p83) the Prophet (SAW) says: There is a piece of flesh in the body, if it becomes good (reformed), the whole body becomes good, but if it gets spoilt, the whole body gets spoilt, and that is the heart. In (Ibn. Majah, 2007:vol. 5, no. 4143, p310), prophet illustrates the relevance of the state of the human heart to moral judgment. AlIah does not look at your forms or your wealth rather He looks at your deeds and your hearts. To attain a pure state of heart so that human utterances and actions receive commendation in the sight of the creature, knowledge is necessary.

Furthermore, (Laeheem, 2004) posits that knowledge of Islam helps greatly in moral reformation as discernible in children who receive proper Islamic upbringing from childhood. These children tend to exhibit acts of bashfulness, truthfulness, uprightness and consciousness 
of Allah in all their dealings. The Qur'an (35:28) attests to the above assertion as it says: Those truly fear Allah, among His Servants, who have knowledge: for Allah is Exalted in Might, Oft-

Forgiving.

\section{Conclusion}

The above exposition dwells on the concept of knowledge which it categorises into two. In addition, it provides logical evidences buttressing the key role of knowledge towards realisation of the essence of creation. The paper stresses that to be able to worship God, man needs to understand properly the concept of Tawhid, the knowledge of Islamic jurisprudence and other basic knowledge. The need to acquire any other necessary aspect of knowledge that is Fard kifayah is also emphasized.

\section{References}

Anam, K. (2017). Konsep Ibadah Perspektif Pendidikan Islam Dalam Surat An-Nahl Ayat 125 (Kajian Tafsir al-Qurthubi. Unipdu Jombang. http://eprints.unipdu.ac.id/id/eprint/768

Abu Dawud S. A (2008). Sunan Abu Dawud English Arabic-English Trans. by Yaser Q. Saudi Arabia: Darus Salam

Asf ahani, R., Muhammad., H \& Qasim, A., (1992). Mufra dat a lfaz al-Qur'an, Damascus, Syria

Al-Ghazali, I., (2001)., Ihya Ulumul- Din, Eng Translation by Fazlu, K., New Delhi:Yassar Publishers \& Perfumers

Augus S, \& Christine A. L., (2010). Oxford English Dictionary.United United Kingdom:Oxford University Press.

Brooking, A., (1999). Corporate memory: Strategies for Knowledge Management. London

Bukhari, M. I. (1997). Sahih Al-Bukhāri, Arabic-English, by Muhsin M. Khan. Saudi Arabia: Dārussalām

Bukhari M. I. (2007). Adab Al-Mufrad Al-Jāmi lil Ādāb Ān Nubuwah, Cairo: Jawhar Publisher.

Ibn Ishaq (2004), The life of Muhammad, Translated by: Guillaume ,A., Karachi: Oxford University Press

Ibn. Mājah, M. (2007). Sunan Ibn. Mājah. Arabic-English Trans. by Nasiruddin al- Khattab Translation. Saudi Arabia: Dārussalām

Ibn. Kathir I.U (2003). Misbāul- Munir Fi Tahdhib Abridged Version. Saudi Arabia: Dār As-Salām.

Kosim, M. (2008). ILMU PENGETAHUAN DALAM ISLAM (Perspektif Filosofis-Historis). Tadris Jurnal Pendidikan Islam, 3(2). https://doi.org/https://doi.org/10.19105/tjpi.v3i2.232

Laeheem, K. (2014). Factors Associated with Islamic Behavior among Thai Muslim Youth in the Three Southern Border Provinces, Thailand. Kasetsart Journal: Social Sciences, 35(2), $356 \mathrm{e} 367$

Muslim I.H. (2007). Sahih Muslim Trans. by Nasiruddin Khattab, Saudi Arabia: Darussalam 
Osman, B., (1991). Tauhid and Science: Essays on the History and Philosophy of Islamic Science. Kuala Lumpur: Secretariat for Islamic Philosophy and Science

Rubini, R. (2019). PENDIDIKAN MORAL DALAM PERSPEKTIF ISLAM. Al-Manar, 8(1), 225-271. https://doi.org/10.36668/jal.v8i1.104

Sari, M., \& Asmendri. (2018). Metode Penelitian Kepustakaan (Library Research). Penelitian Kepustakaan (Library Research) dalam Penelitian Pendidikan IPA, 2(1).

Sugiyono. (2019). Metode Penelitian Pendidikan. Bandung: Alfabeta.

Qutb, S (2003) In the Shade of the Qur'an, Trans and Ed. by Salabi, A. \& Shamis, A., Islamic Foundation, United Kingdom,

Tirmidhi I. M. (2007). Jami al-Tirmidhi Trans. by Abu Khaliyl. Saudi Arabia: Darussalam. 